\title{
The Optical Properties of Black Coatings and Their Estimated Cooling Effect and Cooling Energy Savings Potential
}

\author{
Jie Qin', Jian Qu' ${ }^{1}$ Jianrong Song1, Zhongnan Song1, Weidong Zhang1*, Yunxing Shi', \\ Tao Zhang1, Xiao Xue ${ }^{2}$, Rongpu Zhang1 ${ }^{1}$, Hongqiang Zhang1, Ziying Zhang1, Xiong Wu ${ }^{1}$ \\ ${ }^{1}$ Technical Center, China State Construction Engineering Co., Ltd., Beijing, China \\ ${ }^{2}$ Department of Chemistry, Renmin University of China, Beijing, China \\ Email: ${ }^{*}$ zhang.weidong@cscec.com
}

Received November 2013

\begin{abstract}
The optical properties of coatings pigmented with different black colorants were systematically investigated and their surface temperatures and cooling energy savings were estimated. The black coatings pigmented with chromite iron nickel black and manganese ferrite black spinel colorants are not cool enough to be energy efficient cool black coatings. The cool black coatings pigmented with NIR-transmitting perylene black and dioxazine purple colorants possess a green shade and a violet shade, respectively. The estimated surface temperature reduction values and annual cooling energy savings in Beijing range from $3.0^{\circ} \mathrm{C}$ and $1.21 \mathrm{kWhm}^{-2} \mathrm{yr}^{-1}$ for the black coating pigmented with chromite iron nickel colorant to $13.8^{\circ} \mathrm{C}$ and $5.52 \mathrm{kWhm}^{-2} \mathrm{yr}^{-1}$ for the black coating pigmented with dioxazine purple colorant, respectively.
\end{abstract}

\section{Keywords}

Solar Reflectance; Thermal Emittance; Pigment; Black Coating; Cooling Effect; Cooling Energy Savings

\section{Introduction}

Generally speaking, the coolest white roof coatings are conventionally not accepted by owners of homes with flat and/or low slop roofs, who often prefer non-white roofs for aesthetic and visual reasons [1-7]. Of the available cool colored coatings, the cool black coating is one option in China. However, a coating must at least absorb practically the entire spectrum of visible light to show a black appearance. In some circumstances, the black coatings, such as those pigmented with carbon black and copper chromite black colorants, not only absorb all the incident visible light (VIS) but also nearly the entire near infrared (NIR) rays, greatly rising the roof surface temperature [1]. Apparently, pigments exert the principal influence on the optical and near-infrared properties of coatings [8] and play a very important role in formulating the cool black coatings.

*Corresponding author.

How to cite this paper: Qin, J., Qu, J., Song, J.R., Song, Z.N., Zhang, W.D., Shi, Y.X., Zhang, T., Xue, X., Zhang, R.P., Zhang, H.Q., Zhang, Z.Y. and Wu, X. (2014) The Optical Properties of Black Coatings and Their Estimated Cooling Effect and Cooling Energy Savings Potential. Journal of Power and Energy Engineering, 2, 68-75. http://dx.doi.org/10.4236/jpee.2014.24011 
In a previous study [9], the NIR properties of 87 single-pigment paint films were characterized. Among the selected black pigments, chromite iron nickel black (C. I. pigment black 30), perylene black (C. I. Pigment black 32) and dioxazine purple (C. I. Pigment violet 23) were identified to be NIR-transmitting colorants, showing both strong NIR backscattering and weak NIR absorption in a binder of refractive index 1.5 [9]. In addition, in the preparation of cool black coatings, we found that manganese ferrite black spinel (C. I. Pigment black 26) is a colorant that is cooler than carbon black and copper chromite black colorants.

In this paper, the optical properties of the cool black coatings pigmented with the above four cool black pigments are investigated and compared with the black coatings pigmented with carbon black and copper chromite black colorants. Their cooling effects and cool energy savings in Beijing are estimated and discussed.

\section{Experimental}

\subsection{Selection of Materials}

To prepare the conventional and cool black coatings, a pure acrylic emulsion and commercially available carbon black, copper chromite, chromite iron nickel black, manganese ferrite black spinel, perylene black and dioxazine purple pigments were selected. Talcum was also selected as extender pigment since it is transparent and non-reflective throughout the visible and near-infrared regions and thus does not interfere the performance of other pigments $[8,10]$. In addition, appropriate paint additives, such as a wetting agent, a dispersant, an antifoaming agent, a leveling agent and a coalescent were also selected to improve the quality and performance of the coatings. All the above materials were used as received to prepare the conventional and cool black coatings. The composition of these coatings is listed in Table 1.

\subsection{Preparation of Conventional and Cool Black Coatings}

The preparation process of the conventional and cool black coatings was as follows: the acrylic emulsion and talcum were first added into the mixing setup, followed by the addition of the wetting agent, dispersant and leveling agent. The mixture was stirred at high speeds for $30 \mathrm{~min}$ and then the prefabricated black pigment dispersion was pumped into paint mixing setup. At this stage, the antifoaming agent and coalescent were added and the mixture was continuously mixed at high speed for $30 \mathrm{~min}$. Finally, the water was added to adjust the viscosity of the coatings.

\subsection{Preparation of Conventional and Cool Black Coating Samples}

To study the optical properties of the conventional and cool black coatings, the above coatings were sprayed on to bare aluminum alloy substrates and those painted with a self-manufactured cool white basecoat, whose optical

Table 1. The composition of the conventional and cool black coatings.

\begin{tabular}{cc}
\hline Component & Content by weight (\%) \\
\hline Pure acrylic emulsion $^{\mathrm{a}}$ & 54.5 \\
Black pigment $^{\mathrm{a}}$ & 5.0 \\
Talcum & 25.0 \\
Wetting agent & 0.5 \\
Dispersant & 0.5 \\
Antifoaming agent & 0.5 \\
Leveling agent & 0.5 \\
Coalescent & 0.5 \\
Water & 13.0 \\
\hline
\end{tabular}

${ }^{\mathrm{a}}$ The black pigment might be carbon black, copper chromite, chromite iron nickel black, manganese ferrite black spinel, perylene black or dioxazine purple. 
and physicochemical properties were described in detail somewhere else [11-13]. The coating thickness ranged from 100 to $150 \mu \mathrm{m}$.

\subsection{Spectral Reflectance and Lightness Measurements}

According to ASTM E903-96 (Standard test method for solar absorbance, reflectance and transmittance of materials using integrating spheres), the spectral reflectance of conventional and cool black coatings over white basecoats and/or bare aluminum alloy substrates was measured using a UV/VIS/NIR spectrophotometer (Perkin Elmer Lambda 750) equipped with an integrating sphere (150-mm diameter, Lab sphere RSA-PE-19). The solar reflectance was computed by integrating the measured spectral data weighted with the air mass 1.5 beam-normal solar spectral irradiance.

The lightness (also referred to as hue, saturation and brightness) of the conventional and cool black coatings were measured using a color reader (CR-10, Konica Minolta Sensing, Inc.).

\subsection{Thermal Emittance Measurements}

The thermal emittance of the black coatings was measured using a portable differential thermopile emissometer AE1 (Devices \& Services Co., Dallas, TX) according to ASTM C 1371 (Standard test method for determining the emittance of materials near room temperature using portable emissometers).

\section{Results and Discussion}

\subsection{The Optical Properties of Black Coatings}

Figure 1 shows the spectral reflectance curves for the black coatings pigmented with carbon black and copper chromite black colorants over bare aluminum alloy substrates and cool white basecoats, whose solar reflectance is approximately 0.89 . The corresponding computed solar and spectral reflectance values, along with the lightness of the coatings, are summarized in Table 2. As shown in Figure 1 and Table 2, for both the coatings pigmented with carbon black and copper chromite black pigments, the spectral reflectance curve of the coating over an aluminum alloy and that over a cool white basecoat overlap and they show very low reflectance over the entire solar spectrum (250 - $2500 \mathrm{~nm}$ ), indicating that both pigments are completely solar absorptive (or non-spectrally selective) pigments. As expected, both the coatings show jet black appearance and possess similar solar reflectance. Unexpectedly, the black coating pigmented with copper chromite black colorant shows lower ultraviolet (UV) and VIS reflectance and lightness but higher NIR reflectance than those of the black coating pigmented with carbon black. The appearance of the coating pigmented with copper chromite black colorant is darker.

The spectral reflectance curves for the black coatings pigmented with chromite iron nickel black, manganese ferrite black spinel black, perylene black and dioxazine purple colorants over bare aluminum alloy substrates and white basecoats are presented in Figure 2. The computed solar and spectral reflectance values and the measured lightness of these four black coatings are listed in Table 3. As indicated in Figures 2(a) and 2(b) and Table 3, the black coatings pigmented with chromite iron nickel black and manganese ferrite black spinel black
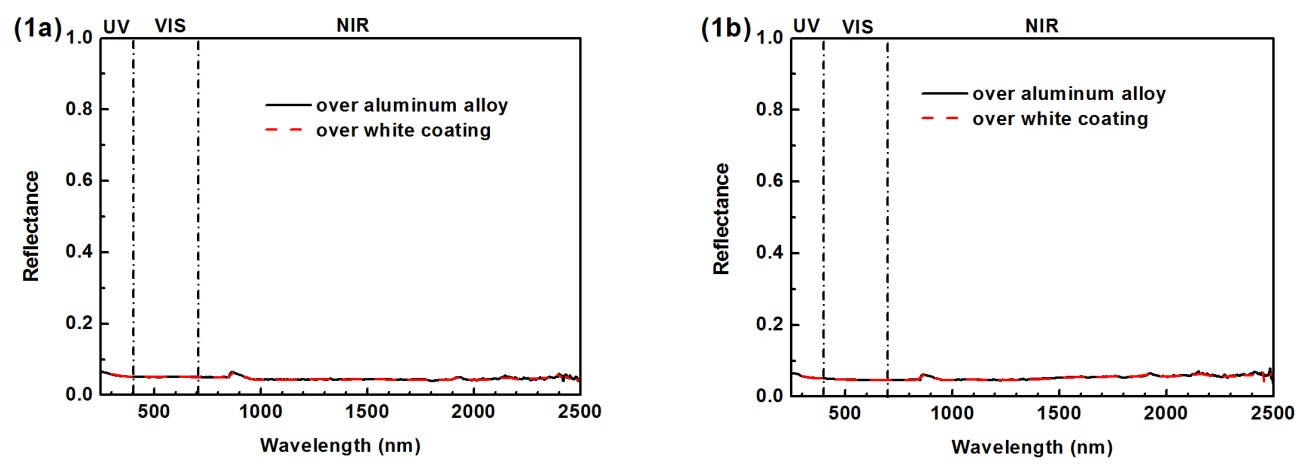

Figure 1. Spectral reflectance curves for the black coatings pigmented with (a) carbon black and (b) copper chromite black colorants over bare aluminum alloy substrates and white basecoats. 
Table 2. Spectral and solar reflectance values as well as lightness for the black coatings pigmented with carbon black and copper chromite black colorants over aluminum alloys and white basecoats.

\begin{tabular}{|c|c|c|c|c|c|c|c|c|}
\hline \multirow{2}{*}{\multicolumn{2}{|c|}{ Samples }} & \multicolumn{4}{|c|}{ Reflectance } & \multicolumn{3}{|c|}{ Lightness } \\
\hline & & Solar & UV & VIS & NIR & $\mathrm{L}^{*}$ & $a^{*}$ & $b^{*}$ \\
\hline \multirow{2}{*}{ Carbon black } & Over aluminum & 0.049 & 0.053 & 0.050 & 0.048 & 26.2 & -2.4 & 1.6 \\
\hline & Over white & 0.049 & 0.053 & 0.050 & 0.047 & 25.1 & -2.5 & 1.4 \\
\hline \multirow{2}{*}{$\mathrm{Cu}-\mathrm{Cr}$ black } & Over aluminum & 0.049 & 0.052 & 0.047 & 0.051 & 25.6 & -2.7 & 1.0 \\
\hline & Over white & 0.049 & 0.052 & 0.047 & 0.051 & 25.7 & -2.7 & 1.0 \\
\hline
\end{tabular}

Table 3. Spectral and solar reflectance values as well as lightness for the black coatings pigmented with chromite iron nickel black, manganese ferrite black spinel, perylene black and dioxazine purple colorants over aluminum alloys and white basecoats.

\begin{tabular}{|c|c|c|c|c|c|c|c|c|}
\hline \multirow{2}{*}{\multicolumn{2}{|c|}{ Samples }} & \multicolumn{4}{|c|}{ Reflectance } & \multicolumn{3}{|c|}{ Lightness } \\
\hline & & Solar & UV & VIS & NIR & $\mathrm{L}^{*}$ & $a^{*}$ & $\mathrm{~b}^{*}$ \\
\hline \multirow{2}{*}{ Cr-Fe black } & Over aluminum & 0.115 & 0.058 & 0.058 & 0.194 & 27.0 & -1.5 & 1.3 \\
\hline & Over white & 0.113 & 0.057 & 0.058 & 0.190 & 27.0 & -1.5 & 1.4 \\
\hline \multirow{2}{*}{ Mn-Fe black } & Over aluminum & 0.126 & 0.058 & 0.058 & 0.221 & 27.6 & -0.8 & 1.5 \\
\hline & Over white & 0.124 & 0.055 & 0.056 & 0.219 & 26.9 & -0.8 & 1.7 \\
\hline \multirow{2}{*}{ Perylene black } & Over aluminum & 0.262 & 0.055 & 0.060 & 0.538 & 25.2 & -2.7 & 1.1 \\
\hline & Over white & 0.307 & 0.053 & 0.062 & 0.640 & 25.9 & -2.9 & 1.2 \\
\hline \multirow{2}{*}{$\begin{array}{l}\text { Dioxazine } \\
\text { purple }\end{array}$} & Over aluminum & 0.298 & 0.054 & 0.098 & 0.572 & 25.6 & 1.3 & -3.4 \\
\hline & Over white & 0.334 & 0.054 & 0.107 & 0.644 & 26.0 & 0.8 & -1.1 \\
\hline
\end{tabular}
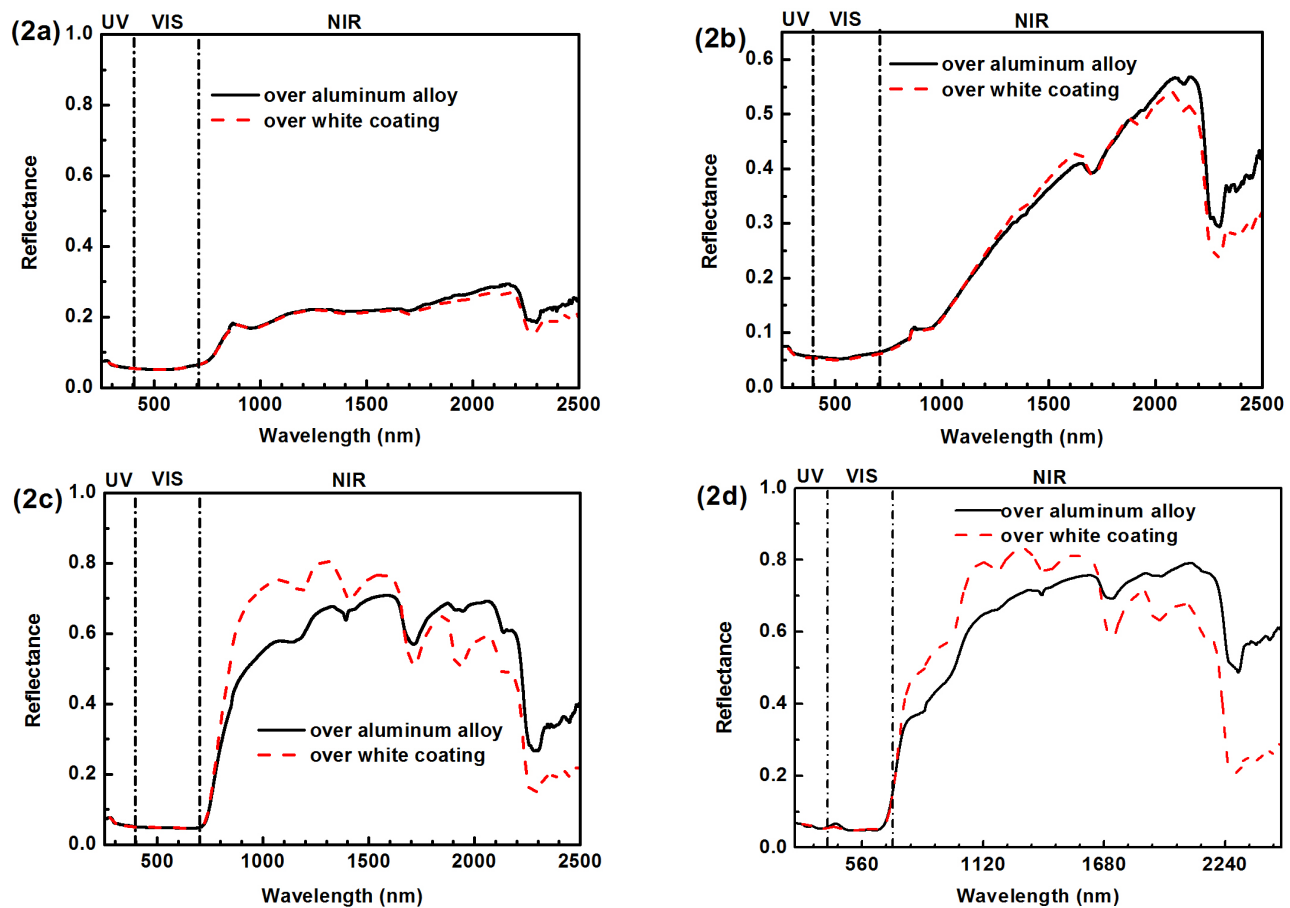

Figure 2. Spectral reflectance curves for the black coatings pigmented with (a) chromite iron nickel black, (b) manganese ferrite black spinel black, (c) perylene black and (d) dioxazine purple colorants over bare aluminum alloy substrates and white basecoats. 
colorants have higher solar, VIS and NIR reflectance and lightness than those of the black coatings pigmented with carbon black and copper chromite black colorants. As specified by China building industrial standard JG/T 235-2011 (architectural solar reflective thermal insulation coatings), for the cool coatings with lightness $\mathrm{L}^{*}$ smaller than 40 , their NIR reflectance should not be smaller as 0.4 . Although the solar reflectance of the black coatings pigmented with chromite iron nickel black and manganese ferrite black spinel black colorants is higher than that of the black coatings pigmented with carbon black and copper chromite black colorants, their NIR reflectance is far smaller than 0.4 (Table 3) and thus they cannot be viewed as qualified cool black coatings without modifications of the coatings' formulations.

Unlike what is observed in Figures 2(a) and 2(b), in the wavelength region from 700 to $1700 \mathrm{~nm}$, the NIR reflectance of the black coatings pigmented with perylene black and dioxazine purple colorants over white basecoats is higher than that over aluminum alloy substrates, while the NIR reflectance of the black coatings pigmented with perylene black and dioxazine purple colorants over white basecoats is lower than that over aluminum alloy substrates. Because half the NIR solar energy (a quarter of the total solar energy) lies within the shorter NIR wavelengths $(700-1000 \mathrm{~nm})$ and $30 \%$ lies within 1000 - $1500 \mathrm{~nm}$ [10], the NIR reflectance over the entire NIR region and consequently the solar reflectance of these two black coatings over cool white basecoats are much higher than those over bare aluminum alloy substrates. The VIS reflectance and lightness of the black coatings pigmented with perylene black and dioxazine purple colorants over white basecoats are higher than those over aluminum alloy substrates. Obviously, perylene black and dioxazine purple colorants are NIRtransmitting pigments because the NIR reflectance of NIR-transmitting colorants highly depends on NIR- reflecting background [9-10]. As indicated by the $\mathrm{a} *$ and $\mathrm{b} *$ values in Table 3, when used as tints, the black coatings pigmented with perylene black and dioxazine purple colorants have a green shade and a violet shade, respectively. Because the lightness of the black coatings pigmented with perylene black and dioxazine purple colorants is much smaller than 40 but their NIR reflectance is much higher than 0.4 , these two black coatings are apparently cool coatings according to China building industrial standard JG/T 235-2001, although only a metameric match to the desired black color is made. According to complementary color theory, to yield a non-metameric match to the desired jet black color, a colorant such as red or yellow iron oxide, respectively, should be added to the green shaded and violet shaded black coatings to re-establish a true black shade.

In a previous study [14], the NIR and solar reflectance of the cool non-white coatings pigmented with NIRtransmitting colorants were found to increase as the coating thickness and pigment concentration decrease. As mentioned above, the thickness of the black coatings developed in this work was between 100 and $150 \mu \mathrm{m}$. The solar reflectance of the cool black coatings pigmented with perylene black and dioxazine purple colorants may be further improved by reducing the coating thickness and pigment concentration.

\subsection{Estimated Surface Temperatures and Cooling Effect}

Two ways may be employed to assess the true cooling effect of a coating. One way is to measure the surface temperature of the coating in the sun in a sunny calm summer day. However, it is not always available and the measurement conditions change over time. An alternative is to estimate the surface temperature of the coating following ASTM E 1980-01 (standard practice for calculating solar reflectance index of horizontal and low sloped opaque surfaces) under the following conditions: insolation $=1000 \mathrm{~W} / \mathrm{m}^{2}$, sky temperature $=300 \mathrm{~K}$, ambient air temperature $=310 \mathrm{~K}$ and convection coefficient (medium wind) $=12 \mathrm{~W} /\left(\mathrm{m}^{2} \mathrm{~K}\right)$. The estimated surface temperatures of the black coatings and surface temperature reduction values relative to that of the black coating pigmented with carbon black and/or copper chromite black colorants are tabulated in Table 4.

As indicated in Table 4, under the standard conditions specified by ASTM E 1980-01, the surface temperature reduction values of the black coatings pigmented with chromite iron nickel black and manganese ferrite black spinel black colorants are approximately $3.0^{\circ} \mathrm{C}$ and $3.6^{\circ} \mathrm{C}$, respectively. The surface temperature reduction values of the black coatings pigmented with perylene black and dioxazine purple colorants over bare aluminum alloy substrates are $11.2^{\circ} \mathrm{C}$ and $12.0^{\circ} \mathrm{C}$, respectively, while over cool white basecoats, these two values are $12.4^{\circ} \mathrm{C}$ and $13.8^{\circ} \mathrm{C}$, respectively. In good agreement with what observed above, the black coatings pigmented perylene black and dioxazine purple colorants are cool coatings.

\subsection{Estimated Cooling Energy Savings of the Coatings in Beijing}

In this section, the most commonly used DOE-2 computations will be used to estimate cooling energy savings in 
Table 4. Estimated surface temperatures of the black coatings and surface temperature reduction values relative to that of the black coating pigmented with carbon black and/or copper chromite black colorants.

\begin{tabular}{cccc}
\hline \multirow{2}{*}{ Samples } & $\begin{array}{c}\text { Surface temperature } \\
(\mathrm{K})\end{array}$ & $\begin{array}{c}\text { Temperature } \\
\text { reduction }\left({ }^{\circ} \mathrm{C}\right)\end{array}$ \\
\hline \multirow{2}{*}{ Carbon black } & Over aluminum & 355.6 & - \\
& Over white & 355.6 & - \\
Cu-Cr black & Over aluminum & 355.6 & - \\
& Over white & 355.6 & - \\
Cr-Fe black & Over aluminum & 352.5 & 3.1 \\
& Over white & 352.6 & 3.0 \\
Mn-Fe black & Over aluminum & 351.9 & 3.7 \\
& Over white & 352.0 & 3.6 \\
Perylene black & Over aluminum & 345.4 & 11.2 \\
& Over white & 343.2 & 12.4 \\
Dioxazine purple & Over aluminum & 343.6 & 12.0 \\
& Over white & 341.8 & 13.8 \\
\hline
\end{tabular}

Beijing due to the applications of black coatings on the roofs. The simulation was based on a simplified model [15] correlating the cooling energy savings and heating penalty to annual cooling degree days (base $18^{\circ} \mathrm{C}$, $\mathrm{CDD} 18$ ) and heating degree days (base $18^{\circ} \mathrm{C}$, HDD18). The simulation is the energy savings relative to a black coating with solar reflectance of 0.05 and thermal emittance of 0.9 . The measured thermal emittance of all the black coatings was approximately 0.9 .

Assuming that the roof insulation of the prototypical model house used in this paper is $\mathrm{R}-5\left(0.87 \mathrm{~m}^{2} \cdot \mathrm{KW}^{-1}\right)$, as is common for the old, flat concrete houses in Beijing, and that the coefficient of performance (COP) of the cooling air conditioner is an average value of 2.0, the simulated cooling energy savings due to the applications of the black coatings pigmented with chromite iron nickel black, manganese ferrite black spinel, perylene black and dioxazine purple colorants over white basecoats in Beijing are compared in Table 5. The simulated annual cooling energy savings in Beijing are $1.21 \mathrm{kWhm}^{-2} \mathrm{yr}^{-1}$ for the coating pigmented with chromite iron nickel black colorant, $1.35 \mathrm{kWhm}^{-2} \mathrm{yr}^{-1}$ for the coating pigmented with manganese ferrite black spinel colorant, 4.98 $\mathrm{kWhm}^{-2} \mathrm{yr}^{-1}$ for the coating pigmented with perylene black colorant and $5.52 \mathrm{kWhm}^{-2} \mathrm{yr}^{-1}$ for the coating pigmented with dioxazine purple colorant.

Beijing is located in northern China with latitude of approximately $40^{\circ} \mathrm{N}$ and in the warm temperate continental monsoon climate zone. It is common knowledge that the cooling energy savings due to the applications of cool roof coatings positively correlate with the ambient temperature at the constant solar reflectance and thermal emittance of the applied cool coatings and the constant roof insulation and COP. Therefore, it is reasonable to expect a larger cooling energy savings for the places in the subtropical monsoon climate zone and tropical monsoon climate zone in China, where the monthly average ambient temperatures in the summer are higher than those in Beijing.

\section{Conclusions}

Based on the new findings in this work, the following conclusions may be drawn:

- The black coatings pigmented with chromite iron nickel black and manganese ferrite black spinel colorants in this work are actually not cool coatings, although their solar reflectance is higher than that of the black coatings pigmented with carbon black and copper chromite black colorants.

- The black coatings pigmented with NIR-transmitting perylene black and dioxazine purple colorants are cool black coatings, although they have a green and a violet shade, respectively.

- The surface temperature reduction values of the black coatings pigmented with perylene black and dioxazine purple colorants over bare aluminum alloy substrates are $11.2^{\circ} \mathrm{C}$ and $12.0^{\circ} \mathrm{C}$, respectively, while these two values are $12.4^{\circ} \mathrm{C}$ and $13.8^{\circ} \mathrm{C}$ over cool white basecoats, respectively. 
Table 5. Estimated cooling energy savings for the cool black roof coatings pigmented with chromite iron nickel black, manganese ferrite black spinel, perylene black and dioxazine purple colorants over white basecoats in Beijing.

\begin{tabular}{cc}
\hline Coatings & Annual cooling energy savings $\left(\mathrm{kWhm}^{-2} \mathrm{yr}^{-1}\right)$ \\
\hline Cr-Fe black & 1.21 \\
Mn-Fe black & 1.35 \\
Perylene black & 4.98 \\
Dioxazine purple & 5.52 \\
\hline
\end{tabular}

- The estimated energy savings due to applications of black coatings in Beijing range from $1.21 \mathrm{kWhm}^{-2} \mathrm{yr}^{-1}$ for the coating pigmented with chromite iron nickel black colorant to $5.52 \mathrm{kWhm}^{-2} \mathrm{yr}^{-1}$ for the coating pigmented with dioxazine purple colorant.

\section{Acknowledgements}

This work was performed under the "Water-Borne Cool Coatings for Building Energy Efficiency” project with funding from the Technical Center of China State Construction Engineering Co., Ltd.

\section{References}

[1] Akbari, H., Levinson, R., Miller, W. and Berdahl, P. (2005) Cool Colored Roofs to Save Energy and Improve Air Quality. Passive and Low Energy Cooling for the Built Environment, Santorini, 19-21 May 2005, 89-100.

[2] Levinson, R., Berdahl, P., Akbari, H., Miller, W., Joedicke, I., Reilly, J., Suzuki, Y. and Vondra, M. (2007) Methods of Creating Solar-Reflective Nonwhite Surfaces and their Application to Residential Roofing Materials. Solar Energy Materials and Solar Cells, 91, 304-314. http://dx.doi.org/10.1016/j.solmat.2006.06.062

[3] Levinson, R., Akbaria, H. and Reilly, J.C. (2007) Cooler Tile-Roofed Buildings with Near-Infrared-Reflective Non-White Coatings. Building and Environment, 42, 2591-2605. http://dx.doi.org/10.1109/mitp.2008.113

[4] Santamouris, M., Synnefa, A. and Karlessi, T. (2011) Using Advanced Cool Materials in the Urban Built Environmentto Mitigate Heat Islands and Improve Thermal Comfort Conditions. Solar Energy, 85, 3085-3102. http://dx.doi.org/10.1016/j.solener.2010.12.023

[5] Synnefa, A., Santamouris, M. and Apostolakis, K. (2007) On the Development, Optical Properties and Thermal Performance of Cool Colored Coatings for the Urban Environment. Solar Energy, 81, 488-497. http://dx.doi.org/10.1016/j.solener.2006.08.005

[6] Uemoto, K.L., Sato, N.M.N. and John, V.M. (2010) Estimating Thermal Performance of Cool Colored Paints. Energy and Buildings, 42, 17-22. http://dx.doi.org/10.1016/j.enbuild.2009.07.026

[7] Hellring, S.D. and Mcquown, S.G. (2012) Coating Compositions That Transmit Infrared Radiation and Exhibit Color Stability and Related Coating Systems. EU Patent No. WO2012170230.

[8] Brady, R.F. and Wake, L.V. (1992) Principles and Formulations for Organic Coatings with Tailored Infrared Properties. Progress in Organic Coatings, 20, 1-25. http://dx.doi.org/10.1016/0033-0655(92)85001-C

[9] Levinson, R., Berdahl, P. and Akbari, H. (2005) Solar Spectral Optical Properties of Pigments-Part II: Survey of Common Colorants. Solar Energy Materials and Solar Cells, 89, 351-389. http://dx.doi.org/10.1016/ j.solmat.2004.11.013

[10] Bendiganavale, A.K. and Malshe, V.C. (2008) Infrared Reflective Inorganic Pigments. Recent Patents on Chemical Engineering, 1, 67-79. http://dx.doi.org/10.2174/2211334710801010067

[11] Shi, Y., Song, Z., Zhang, W., Song, J., Qu, J., Wang, Z., Li, Y., Xu, L. and Lin, J. (2013) Physicochemical Properties of Dirt-Resistant Cool White Coatings for Building Energy Efficiency. Solar Energy Materials \& Solar Cells, 110, 133-139. http://dx.doi.org/10.1016/j.solmat. 2012.12.011

[12] Song, Z., Zhang, W., Shi, Y., Song, J., Qu, J., Qin, J., Zhang, T., Li, Y., Zhang, H. and Zhang, R. (2013) Optical Properties across the Solar Spectrum and Indoor Thermal Performance of Cool White Coatings for Building Energy Efficiency. Energy and Buildings, 63, 49-58. http://dx.doi.org/10.1016/j.enbuild.2013.03.051

[13] Zhang, W., Song, Z., Shi, Y., Song, J., Qu, J., Qin, J., Zhang, T., Li, Y., Xu, L. and Xue, X. (2013) The Effects of Manufacturing Processes and Artificial Accelerated Weathering on the Solar Reflectance and Cooling Effect of Cool Roof Coatings. Solar Energy Materials and Solar Cells, 118, 61-71. http://dx.doi.org/10.1016/ j.solmat.2013.07.039 
[14] Song, Z., Qin, J., Qu, J., Song, J., Zhang, W., Shi, Y., Zhang, T., Xue, X., Zhang, R., Zhang, H., Zhang, Z. and Wu, X. (Unpublished) A Systematic Investigation on Factors Affecting The Spectral Reflectance of Cool Non-White Coatings.

[15] Wilkes, K.E. (1989) Model for Roof Thermal Performance. Oak Ridge National Laboratory. 